\title{
SINTESIS DAN KARAKTERISASI MEMBRAN KITOSAN UNTUK APLIKASI SENSOR DETEKSI LOGAM BERAT
}

\author{
Agung Nugroho CS*, Nanik Dwi Nurhayati, Budi Utami \\ Program Studi Pendidikan PMIPA FKIP Universitas Sebelas Maret \\ Jl. Ir. Sutami 36 A, Kentingan, Surakarta 57126 \\ email : anc_saputro@yahoo.co.id.
}

\begin{abstract}
ABSTRAK
Penelitian tentang pemanfaatan membran kitosan sebagai sensor deteksi logam berat berdasarkan sifat optic belum pernah dilaporkan. Penelitian ini melaporkan kajian tentang sintesis membrane kitosan untuk diaplikasikan sebagai sensor deteksi logam berat berdasarkan sifat optic. Sebagai laporan awal, pada artikel ini baru akan dilaporkan kajian sintesis membrane kitosan dari serbuk kitosan hasil preparasi dari cangkang kepiting dan karakterisasinya. Penelitian awal ini bertujuan untuk mensintesis membrane kitosan dari serbuk kitosan dan karakterisasinya. Serbuk kitosan dipreparasi dari cangkang kepiting melalui proses deproteinasi, demineralisasi dan deasetilasi. Membran kitosan dibuat dari kitosan dengan penambahan agen crosslingking berupa glutaraldehida. Kitosan dikarakterisasi meliputi uji kadar air, kadar abu, kadar nitrogen, viskositas, derajat deasetilasi, analisis gugus fungsi dengan spektroskopi IR dan kristalinitas dengan difraksi sinar X. Membran kitosan dilakukan karakterisasi penampilan fisik, analisis gugus fungsi dan kristalinitas. Kesimpulan penelitian adalah 1). Kitosan dapat dipreparasi dari limbah cangkang kepiting melalui proses deproteinasi, demineralisasi, dan deasetilasi., 2). Membran kitosan dapat disintesis dari serbuk kitosan dengan menggunakan agen crosslinking glurataldehida., 3). Semakin tinggi konsentrasi kitosan yang digunakan untuk membuat membran, maka membran yang dihasilkan akan menunjukkan warna yang pekat dan kurang transparan, 4). Struktur kimia kitosan dalam bentuk membran kitosan tidak mengalami perubahan tetapi kristalinitasnya berubah.
\end{abstract}

Kata kunci : membrane kitosan, karakterisasi, sensor deteksi, logam berat

\section{SYNTHESIS AND CHARACTERIZATION OF CHITOSAN MEMBRANES FOR APPLICATION AS A HEAVY METAL DETECTION SENSOR}

\begin{abstract}
Research on the utilization of chitosan membrane as a heavy metal detection sensor based on optical properties has not been reported. This study reported a study on the synthesis of chitosan membranes for application as a heavy metal detection sensor based on optical properties. As reported earlier, in this new article will be reported chitosan membrane synthesis study of the preparation of chitosan powder from crabs shells and characterization. This initial study aims to synthesize membrane of chitosan powder and chitosan characterization. Chitosan powder prepared from the shells of crabs through deproteination, demineralization and deacetylation processes. Chitosan membranes made from chitosan with the addition of glutaraldehyde as crosslingking agent. Chitosan is characterized include testing the water content, ash content, nitrogen content, viscosity,
\end{abstract}


degree of deacetylation, functional group analysis by IR spectroscopy and crystallinity by $\mathrm{X}$-ray diffraction Characterization of chitosan membranes made of physical appearance, the analysis of functional groups and crystallinity. Conclusion The study is 1). Chitosan can be prepared from crab shell waste through a process of deproteination, demineralization, and deacetylation., 2). Chitosan membranes can be synthesized from chitosan powder by using a crosslinking agent glurataldehida., 3). The higher the concentration of chitosan is used to make the membrane, the membrane produced will show a dark color and less transparent, 4). Chemical structure of chitosan in the form of chitosan membrane has not changed but kristalinitasnya changed.

Keywords : chitosan membrane, characterization, detection sensor, heavy metals

\section{PENDAHULUAN}

Sejak kasus kecelakaan merkuri di Minamata Jepang tahun 1953 yang secara intensive dilaporkan, issue pencemaran logam berat meningkat sejalan dengan pengembangan berbagai penelitian yang mulai diarahkan pada berbagai aplikasi teknologi untuk menangani polusi lingkungan yang disebabkan oleh logam berat. Kecemasan yang berlebihan terhadap hadirnya logam berat di lingkungan dikarenakan tingkat keracunannya yang sangat tinggi dalam seluruh aspek kehidupan makhluk hidup (Suhendrayatna, 2001).

Berbagai usaha dilakukan untuk mengurangi logam berat dari lingkungan berair. Penghilangan logam berat dalam air pada konsentrasi tinggi dapat dilakukan dengan menggunakan metode pengendapan kimia atau elektrokimia. Pada konsentrasi rendah, penghilangan logam berat lebih efektif dilakukan dengan menggunakan metode pertukaran ion (ion-exchange) atau adsorpsi dengan absorben padat seperti karbon aktif (Imamoglu dan Teker, 1999) dan membran kitosan (Meriatna, 2008). Menurut penelitian Guzel dan Uzun (2000), absorben kitosan jauh lebih efektif mengadsorpsi ion logam $\mathrm{Fe}^{2+}$, $\mathrm{Ni}^{2+}, \mathrm{Cu}^{2+}$ dibandingkan absorben dari karbon aktif. Hal ini menunjukkan bahwa kitosan mempunyai potensi lebih besar dibandingkan karbon aktif untuk aplikasi adsorpsi logam-logam berat.
Kitosan (poli- $\beta-(1,4)-\mathrm{D}-$ glukosamin) merupakan makromolekul biologi yang dapat diperoleh dari proses deasetilasi dari kitin yang dapat tersedia melimpah pada cangkang kepiting, kulit udang dan cangkang serangga. Kitin (poli- $\beta$ - $(1,4)-\mathrm{N}$-asetil-D-glukosamin) merupakan biopolimer alami kedua terbanyak di alam setelah selulosa (Yanming et al., 2001, Baxter et al., 2005). Setiap tahun sekitar 100 milyar ton kitin diproduksi di permukaan bumi ini oleh krustasea, kerang, rajungan, serangga, jamur dan organisme lainnya. (Rege dan Block, 1999). Kitosan (2asetamidadeoksi- $\beta$-D-glukosa) memiliki gugus asam amino dan gugus hidroksil yang menyebabkan kitosan memiliki reaktifitas kimia yang tinggi sehingga menyebabkan sifat polielektrolit kation dan dapat berperan sebagai penukar ion sehingga kitosan dapat digunakan sebagai pengikat atau absorben logam-logam berat.

Telah banyak laporan tentang aplikasi kitosan untuk mengikat logamlogam berat. Dyahningtyas (1999) telah melaporkan penggunaan kitosan untuk menghilangkan cadmium (Cd) dalam larutan cair. Karthikeyan et al. (2004) meaporkan penggunaan kitosan untuk adsorpsi logam seng (Zn), sedangkan Franco et al. (2004) menggunakan kitosan dari Cunninghamela elegans (IFM 46109) untuk biosorpsi logamlogam berat $\mathrm{Pb}, \mathrm{Fe}$ dan $\mathrm{Cu}$. Semua 
penelitian tersebut melaporkan bahwa kitosan dapat digunakan sebagai absorben atau pengikat logam-logam berat.

Penelitian mengenai modifikasi kitosan telah banyak dilakukan. Kitosan mempunyai sifat mudah larut dalam asam-asam organik. Jika dimanfaatkan sebagai adsorben kitosan kurang resisten terhadap asam. Penambahkan agen pengikat silang (crosslink agent) dapat meningkatkan stabilitas kitosan dalam asam. Kitosan tak berikat silang mempunyai kapasitas adsorpsi lebih besar dari pada kitosan berikat silang, tetapi kitosan berikat silang mempunyai ketahanan fisik terhadap asam yang lebih baik dari pada kitosan tak berikat. Salah satu agen ikat silang adalah gultaraldehid, dengan penambahan glutaraldehid maka kualitas kitosan akan lebih baik.

Salah satu modifikasi kitosan adalah menjadikannya menjadi membran. Dengan modifikasi kitosan menjadi membran kitosan maka pemanfaatan kitosan sebagai agen pengompleks logam berat lebih mudah dilakukan. Meriatna (2008) melaporkan penggunaan membran kitosan untuk menurunkan kadar logam krom dan nikel dalam limbah cair industri pelapisan logam dimana membran kitosan mampu menurunkan kadar logam $\mathrm{Cr}$ sebanyak 99,87\% dan kadar logam Ni sebesar 91,13\%.

Menurut Panggabean (2001), jika kitosan membentuk senyawa kompleks (senyawa kelat) dengan ion-ion logam berat, maka akan ditandai oleh pergeseran bilangan gelombang dari beberapa gugus fungsi. Sebagai contoh jika kitosan membentuk kompleks dengan logam $\mathrm{Cd}$ dan $\mathrm{Cu}$, akan terjadi pergeseran pita $\mathrm{O}=\mathrm{C}-\mathrm{NHR}$ dari daerah $1650 \mathrm{~cm}^{-1}$ menjadi $1625 \mathrm{~cm}^{-1}$; $-\mathrm{NH}_{2}$ bergeser dari daerah $1590 \mathrm{~cm}^{-1}$ menjadi $1575 \mathrm{~cm}^{-1}$ (Panggabean, 2001). Berdasarkan fenomena pergeseran bilangan gelombang dari beberapa gugus fungsi dalam rantai kitosan tersebut, maka kemungkinan peristiwa tersebut dapat dijadikan alternatif cara mendeteksi keberadaan ion-ion logam berat dalam limbah cair. Sepanjang pengetahuan peneliti, belum ada laporan penggunaan sifat optic pergeseran bilangan gelombang gugus fungsi pada proses pembentukan kompleks kitosan-logam sebagai sensor deteksi keberadaan ionion logam berat dalam limbah cair. Dalam penelitian ini dimunculkan inovasi baru pemanfaatan sifat optic pergeseran bilangan gelombang pada pembentukan kompleks kitosan-logam sebagai sensor deteksi logam-logam berat. Oleh karena itu sangat penting dilakukan penelitian kemungkinan penggunaan data pergeseran bilangan gelombang pada proses pembentukan kompleks kitosanlogam sebagai metode sensor deteksi ionion logam berat.

Berdasarkan alur pemikiran di atas, maka dalam penelitian ini akan disintesis kitosan yang selanjutnya dibentuk dalam bentuk membran kitosan dan akan dikontakkan dengan ion-ion logam berat tertentu sehingga terbentuk senyawa kompleks kitosan-logam. Membrane kitosan yang telah terdoping ion-ion logam berat tersebut selanjutnya dilakukan analisis gugus fungsi dengan spektroskopi FT-IR. Spectra FT-IR kitosan sebelum doping dan setelah doping dengan ion-ion logam berat kemudian dibandingkan untuk melihat pergeseran bilangan gelombang gugusgugus fungsinya. Data pergeseran bilangan gelombang yang diperoleh tersebut selanjutnya dapat digunakan sebagai data panduan (referensi) untuk mendeteksi jenis ion logam yang terikat pada rantai kitosan ketika membrane kitosan dikontakkan dengan limbah cair yang mengandung beberapa ion logam berat. Data sifat optic pergeseran bilangan gelombang kompleks kitosanlogam kemungkinan besar dapat dipergunakan sebagai sensor deteksi logam berat karena ikatan kitosan dengan 
ion-ion logam berat bersifat spesifik dan akan memberikan data pergeseran yang spesifik pula untuk setiap logam-logam berat tertentu. Penelitian ini diharapkan dapat memberikan sumbangan pemikiran tentang metode sensor pendeteksi keberadaan logam berat dalam limbah cair secara sederhana dan akurat tanpa merusak sample.

Pada artikel penelitian ini baru akan dilaporkan tahap preparasi kitosan dari limbah cangkang kepiting yang selanjutnya disintesis menjadi membran kitosan dan dilakukan uji karakterisasi, sedangkan untuk aplikasi sensor deteksi logam berat berdasarkan sifat optic akan dilaporkan pada artikel selanjutnya. Tujuan dari penelitian ini adalah untuk 1). Preparasi kitosan dari serbuk cangkang kepiting., 2). Sintesis membran kitosan, 3). Karakterisasi kitosan dan membrane kitosan.

\section{METODE PENELITIAN}

\section{Alat dan Bahan}

Alat-alat yang dipergunakan meliputi seperangkat alat-alat gelas, satu set alat refluks, oven, timbagan analitik, spektroskopi FTIR dan difraksi sinar X (XRD). Bahan-bahan yang dipergunakan dalam penelitian ini meliputi limbah cangkang kepiting, asam asetat (Merck), $\mathrm{NaOH}$ (Merck), $\mathrm{HCl}$ (Merck), dan glurataldehida (Merck).

\section{Prosedur Penelitian}

\section{Preparasi kitosan}

Preparasi kitosan dari limbah cangkang kepiting dilakukan menurut metode (Saputro, 2009., Saputro et al.,2009) berikut :

\section{a. Tahap deproteinasi}

Lima puluh gram sampel serbuk kepiting dimasukkan ke dalam labu leher tiga $500 \mathrm{ml}$ kemudian ditambahkan $\mathrm{NaOH} 4 \%$ dengan perbandingan konsentrasi sampel berbanding $\mathrm{NaOH}$ sebesar 1:10 b/v. Campuran tersebut kemudian dipanaskan dan diaduk pada suhu $80^{\circ} \mathrm{C}$ selama 1 jam pada kondisi refluks. Kemudian campuran di saring dengan menggunakan kertas saring dan residu yang diperoleh dicuci dengan menggunakan aquades sampai netral. Setelah kondisi netral tercapai, residu yang diperoleh kemudian dikeringkan pada suhu $60^{\circ} \mathrm{C}$ selama 48 jam.

\section{b. Tahap demineralisasi}

Sepuluh gram residu hasil deproteinasi dimasukkan ke dalam gelas kimia $600 \mathrm{ml}$ kemudian ditambahkan $\mathrm{HCl} 1 \mathrm{M}$ dengan perbandingan konsentrasi sampel berbanding $\mathrm{HCl}$ sebesar 1:15 b/v. Campuran tersebut kemudian diaduk pada suhu kamar selama 3 jam. Kemudian campuran di saring dengan menggunakan kertas saring dan residu yang berupa kitin yang diperoleh dicuci dengan menggunakan aquades sampai netral. Setelah kondisi netral tercapai, kitin yang diperoleh kemudian dikeringkan pada suhu $60^{\circ} \mathrm{C}$ selama 48 jam.

\section{c. Tahap deasetilasi}

Sepuluh gram kitin dimasukkan ke dalam labu leher tiga $250 \mathrm{ml}$ kemudian ditambahkan $\mathrm{NaOH}$ dengan konsentrasi $50 \%$ dengan perbandingan konsentrasi sampel berbanding $\mathrm{NaOH}$ sebesar 1:15 b/v. Campuran tersebut kemudian dipanaskan dan diaduk pada suhu $100^{\circ} \mathrm{C}$ selama 2 jam pada kondisi refluks. Kemudian campuran di saring dengan menggunakan kertas saring dan residu yang merupakan kitosan dicuci dengan menggunakan aquades sampai netral. Setelah kondisi netral tercapai, kitosan yang diperoleh kemudian dikeringkan pada suhu $60^{\circ} \mathrm{C}$ selama 48 jam. 
Kitosan yang diperoleh selanjutnya dilakukan karakterisasi dengan spektroskopi FT-IR di Laboratorium instrumen Jurusan Kimia FMIPA UGM dan Difraksi sinar X (XRD) di laboratorium Kimia Analitik Jurusan Kimia FMIPA UGM.

\section{d. Pembuatan Membran kitosan}

Metode pembuatan membran kitosan mengadopsi metode Uragami dan Tomaszezka (1994) dalam Meriatna (2008) sebagai berikut : Sebanyak 5 gram kitosan dilarutkan dalam 250 $\mathrm{mL}$ larutan asam asetat $1 \%$ pada temperature kamar. Bahan yang telah dicampur diaduk hingga homogen sehingga diperoleh larutan kitosan $2 \%$, kemudian dituangkan kedalam plat kaca dan dikeringkan pada temperature kamar. Lapisan kitosan $2 \%$ yang diperoleh kemudian dicelupkan dalam larutan $\mathrm{NaOH} 1 \%$ pada temperature kamar dan dilanjutkan pencucian dengan akuades berulang-ulang untuk menghilangkan kadar $\mathrm{NaOH}$ dan dikeringkan. Membran kitosan yang dihasilkan kemudian dicelupkan dalam $50 \mathrm{~mL}$ larutan glutaraldehida $0,4 \%$ yang mengandung $5 \mathrm{~mL} \mathrm{H}_{2} \mathrm{SO}_{4}$ $0,5 \mathrm{~N}$, kemudian dicuci berulangulang dan dikeringkan pada temperature kamar. Mengulangi prosedur a sampai d untuk konsentrasi membrane kitosan 1, 3, 4, dan $5 \%$.

\section{e. Karakterisasi}

Kitosan hasil preparasi dilakukan karakterisasi meliputi uji kadar air, kadar abu, kadar nitrogen, viskositas, derajat deastilasi, analisis gugus fungsi dengan spektroskopi IR dan analisis kristalinitas dengan difraksi sinar X. Sedangkan membran kitosan dikarakterisasi dengan uji penampilan fisik, spektroskopi IR dan difraksi sinar X.

\section{HASIL DAN PEMBAHASAN}

\section{Preparasi Kitosan}

Preparasi kitosan dari limbah cangkang kepiting Jawa secara umum dilakukan melalui 3 tahap perlakuan, yaitu deproteinasi, demineralisasi, dan deasetilasi. Tahap deproteinasi bertujuan untuk menghilangkan protein yang terdapat pada cangkang kepiting. Tahap deproteinasi dilakukan dengan larutan $\mathrm{NaOH} 4 \%$ pada suhu $80^{\circ} \mathrm{C}$ selama 1 jam dan diperoleh rendemen sebesar 80,94\%. Hal ini menunjukkan kalau protein yang hilang proses deproteinasi sebesar $19,06 \%$.

Tahap selanjutnya adalah tahap demineralisasi, yaitu penghilangan mineral-mineral dalam cangkang kepiting dengan menggunakan larutan $\mathrm{HCl} 1 \mathrm{M}$ pada suhu kamar selama 3 jam. Pada tahap ini diperoleh rendemen sebesar $22,95 \%$. Hal ini menunjukkan bahwa sebagian besar komponen penyusun cangkang kepiting adalah mineralmineral logam, khususnya kalsium karbonat $\left(\mathrm{CaCO}_{3}\right)$ dan kalsium fosfat $\left[\mathrm{Ca}_{3}\left(\mathrm{PO}_{4}\right)_{2}\right]$.

Tahap terakhir adalah deasetilasi, yaitu penghilangan gugus asetil. Deasetilasi dilakukan dengan menggunkan larutan $\mathrm{NaOH} 50 \%$ pada suhu $100^{\circ} \mathrm{C}$ selama 2 jam. Pada tahap deasetilasi ini diperoleh rendemen sebesar $70,31 \%$. Pada proses deasetilasi terjadi pemutusan ikatan antara karbon pada gugus asil dengan nitrogen pada kitin menjadi gugus amino. Ketika proses deasetilasi dengan menggunakan larutan $\mathrm{NaOH}$ konsentrasi tinggi, dalam larutannya $\mathrm{NaOH}$ akan terurai menjadi ion $\mathrm{Na}^{+}$dan $\mathrm{OH}^{-}$. Ion hidroksil tersebut lalu menyerang karbon karbonil yang bersifat elektropositif. Produk akhir dari reaksi ini berupa kitosan dan garam natrium asetat sebagai hasil samping. Reaksi deasetilasi kitin dengan basa kuat yang terjadi diperkirakan mengikuti reaksi pada Gambar 1. 


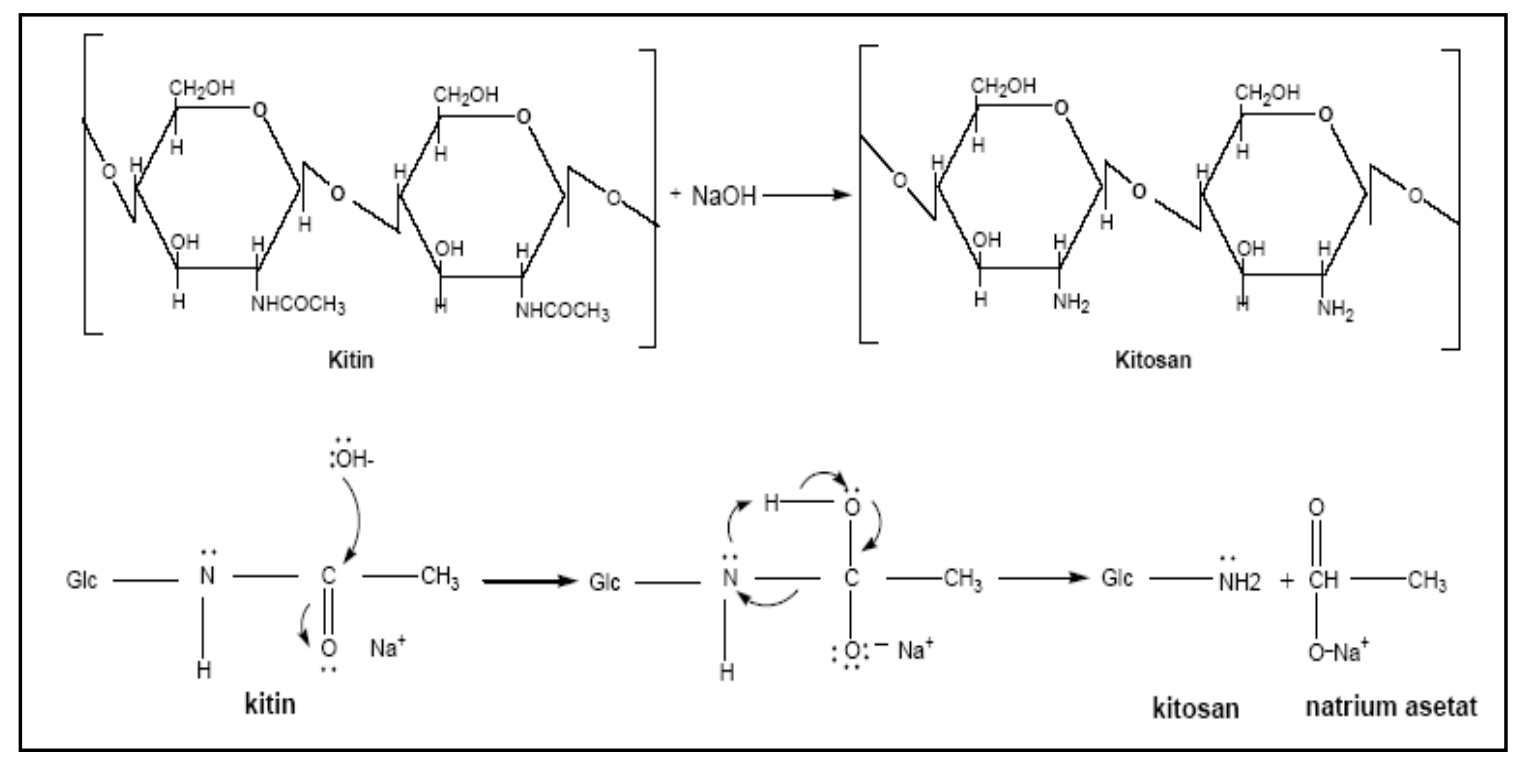

Gambar 1. Reaksi deasetilasi kitin dengan basa kuat menjadi kitosan (Dewi dan Fawzya, 2006)

Tabel 1. Data uji kadar air, kadar abu, kadar nitrogen, viskositas dan derajat deasetilasi Kitin dan Kitosan

\begin{tabular}{|l|c|c|c|c|c|}
\hline Sampel & $\begin{array}{c}\text { Kadar } \\
\text { air (\%) }\end{array}$ & $\begin{array}{c}\text { Kadar } \\
\text { abu (\%) }\end{array}$ & $\begin{array}{c}\text { Kadar N } \\
(\boldsymbol{\%})\end{array}$ & $\begin{array}{c}\text { Viskositas } \\
(\mathbf{c p s})\end{array}$ & $\begin{array}{c}\text { Harga } \\
\text { DD (\%) }\end{array}$ \\
\hline Kitin & 0.0985 & 13,57 & 4,38 & 1,9846 & 62,43 \\
\hline Kitosan & 0,4 & 8,01 & 4,76 & 0.83575 & 79,415 \\
\hline
\end{tabular}

Berdasarkan data rendemen dari tahap deproteinasi, demineralisasi, dan deasetilasi, maka dapat disimpulkan bahwa pada proses preparasi kitosan dari bahan dasar serbuk cangkang kepiting diperoleh rendeman total sebesar $13,06 \%$. Sehingga dari berat serbuk kepiting awal 50 gram akan diperoleh kitosan sebanyak 6,53 gram. Hasil penelitian ini menunjukkan bahwa kandungan kitosan dalam cangkang kepiting sebanyak $13,06 \%$. Kandungan kitosan dalam cangkang kepiting jawa menurut penelitian ini ternyata lebih rendah dibandingkan kandungan kitosan dalam cangkang kepiting Tarakan sebesar 17,05\% (Saputro, 2009).

\section{Karakterisasi Kitosan}

a. Kadar Air, kadar abu, kadar nitrogen, viskositas, dan derajat deasetilasi

Hasil uji kadar air, kadar abu, kadar nitrogen, viskositas dan derajat deasetilasi kitosan hasil preparasi ditampilkan pada Tabel 1. Tabel 1 menunjukkan bahwa kandungan air kitosan lebih banyak daripada kitin. Hal ini menunjukkan bahwa kitosan mempunyai kekuatan mengikat molekulmolekul air lebih kuat dibandingkan kitosan. Lebih banyaknya molekul air yang terikat pada kitosan dibandingkan pada kitin kemungkinan disebabkan oleh lebih banyaknya gugus hidroksil dan 
amino pada kitosan akibat proses deasetilasi, sehingga atom $\mathrm{O}$ pada gugus hidroksil dan atom $\mathrm{N}$ pada gugus amino mengadakan ikatan hydrogen dengan molekul-molekul air.

Kadar nitrogen kitosan lebih tinggi dibandingkan kitin menunjukkan bahwa proses deasetilasi telah terjadi dengan lepasnya gugus-gugus asetil sehingga menurunkan berat total yang mengakibatkan naiknya hasil perhitungan kadar nitrogen.

Kadar abu yang diperoleh dari percobaan ini untuk kitin sebesar $13,57 \%$ dan kadar abu kitosan sebesar 8,01\%. Dari data tersebut menunjukkan bahwa kadar mineral dari kitin ke kitosan mengalami penurunan, hal ini terjadi pada saat proses demineralisasi. Meskipun proses demineralisasi tidak sepenuhnya mampu menghilangkan senyawa anorganik dari cangkang kepiting namun penggunaan asam klorida cukup efektif untuk mengilangkan mineral-mineral anorgani seperti kalsium karbonat maupun kalsium phospat.

Pada percobaan diperoleh nilai viskositas intrinsik kitin adalah 1,9846 cps sedang kitosan sebesar 0,83575cps.
Nilai viskositas kitin lebih besar daripada kitosan, hal ini menunjukkan bahwa kitosan memiliki derajat depolimerisasi yang lebih tinggi daripada kitin. Nilai viskositas berbanding lurus dengan berat molekulnya. Semakin besar harga viskositasnya maka berat molekul suatu senyawa juga semakin besar, begitu pula sebaliknya. Dalam penelitian ini, nilai viskositas kitin lebih besar dibandingkan dengan nilai viskositas kitosan, artinya kitin memiliki berat molekul lebih besar daripada kitosan. Hal tersebut berarti bahwa rantai polimer kitin lebih panjang daripada kitosan.

Harga derajat deasetilasi (DD) kitosan lebih besar dibandingkan kitin. Hal ini menunjukkan bahwa kitosan telah terbentuk dengan lepasnya gugus-gugus asetil melalui proses deasetilasi.

\section{b. Analisis gugus fungsi}

Kitin dan kitosan hasil preparasi dikarakterisasi dengan menggunakan spektroskopi inframerah untuk mengetahui gugus-gugus fungsi karakteristiknya. Spektra IR kitin dan kitosan disajikan dalam Gambar 2.

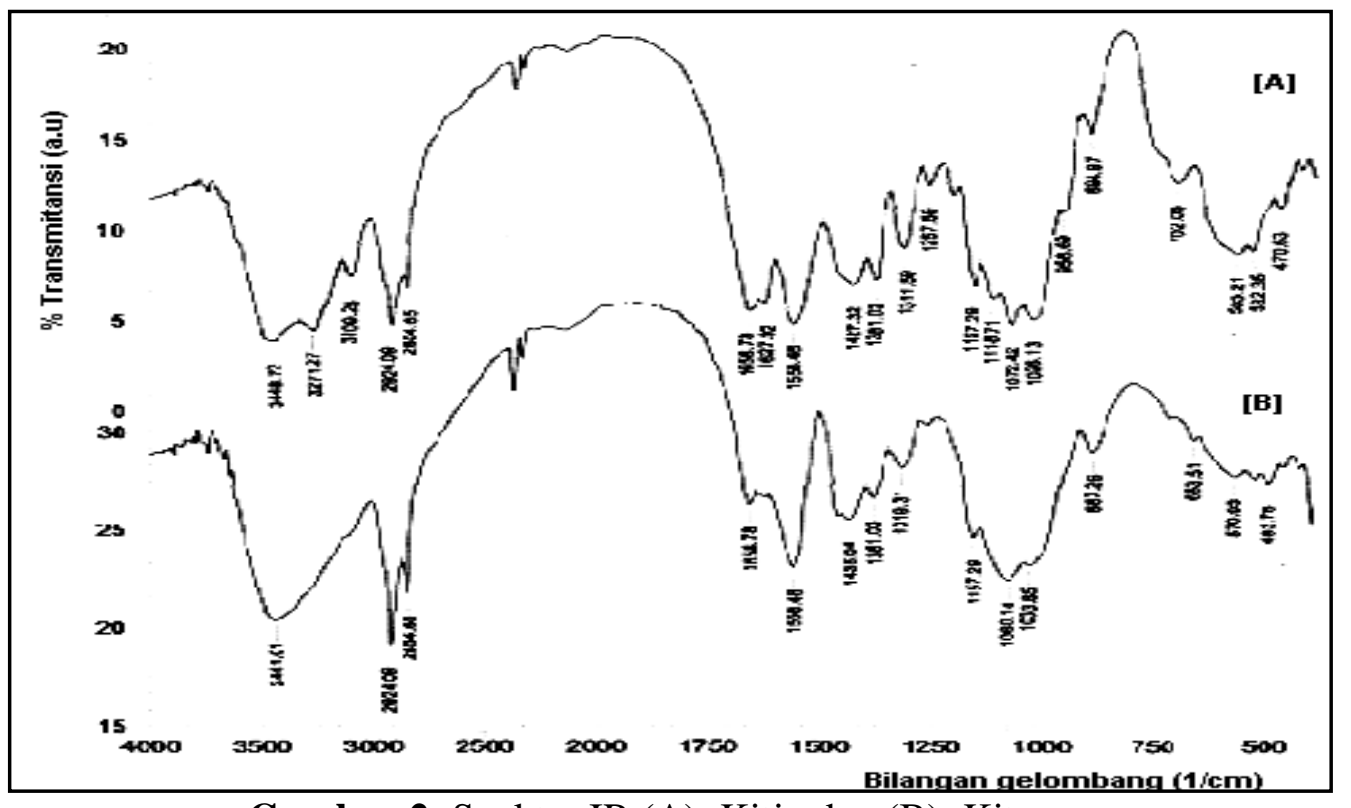

Gambar 2. Spektra IR (A). Kitin dan (B). Kitosan 
Berdasarkan Gambar 2 terlihat bahwa pada spectra IR kitin muncul puncak serapan pada bil.gelombang $3448,72 \mathrm{~cm}^{-1}$ menunjukkan vibrasi ulur gugus $-\mathrm{OH}$. Puncak serapan pada bil.gelombang $2924,09 \mathrm{~cm}^{-1}$ dan $2854,65 \mathrm{~cm}^{-1}$ yang masing-masing merupakan vibrasi ulur simetri $\mathrm{CH}_{3}$ dan vibrasi ulur $\mathrm{C}-\mathrm{H}$, menunjukkan keberadaan gugus asetil (Yanming et al., 2001). Serapan pada bilangan gelombang $1658,78 \mathrm{~cm}^{-1}$ dan $1627,92 \mathrm{~cm}^{-1}$ menunjukkan pita amida I (ulur $\mathrm{C}=\mathrm{O}$ ) dan juga menandakan keberadaan gugus asetil. Bilangan gelombang $1558,48 \quad \mathrm{~cm}^{-1} \quad$ yang merupakan serapan dari amida II (tekuk $\mathrm{NH})$ dan $1311,59 \mathrm{~cm}^{-1}$ menunjukkan serapan amida III (ulur C-N) juga merupakan bukti keberadaan gugus asetil.

Pada spectra IR kitosan muncul puncak serapan pada bilangan gelombang $3441,01 \mathrm{~cm}^{-1}$ menunjukkan serapan vibrasi ulur $-\mathrm{OH}$ yang tumpang tindih dengan vibrasi ulur - $\mathrm{NH}$ (Velde dan Kiekens, 2004). Melebarnya puncak serapan pada bilangan gelombang $3441,01 \mathrm{~cm}^{-1}$ menunjukkan telah terjadinya proses deasetilasi. Masih munculnya serapan amida I $(\mathrm{C}=\mathrm{O})$ pada spektra IR kitosan di 1658,78 dan hilangnya serapan pada $1627,92 \mathrm{~cm}^{-1}$ menunjukkan masih adanya gugus asetil pada rantai polimer kitosan tetapi jumlahnya berkurang akibat proses deasetilasi.

Berdasarkan analisis gugus fungsi di atas, ternyata pada spektra IR kitin dan kitosan menunjukkan munculnya serapan-serapan karakteristik dari kitin dan kitosan. Oleh karena itu, disimpulkan bahwa produk hasil preparasi pada penelitian ini adalah kitosan.

\section{c. Kristalinitas}

Parameter utama yang menentukan sifat kitosan selain berat molekul dan derajat deasetilasi adalah kristalinitas. Kitosan bersifat kristalin dan memperlihatkan polimorfisme tergantung pada keadaan fisiknya. Kajian kristalinitas kitin dan kitosan telah banyak dilaporkan (Cervera et al., 2004., Ogawa et al., 1992., Trung et al., 2006., Twu et al., 2005). Berdasarkan hasil-hasil penelitian disimpulkan bahwa puncak karakteristik kitin dan kitosan berada di sekitar $2 \theta=10^{\circ}$ sampai $2 \theta=20^{\circ}$. Difraktogram XRD kitin dan kitosan disajikan dalam Gambar 3.

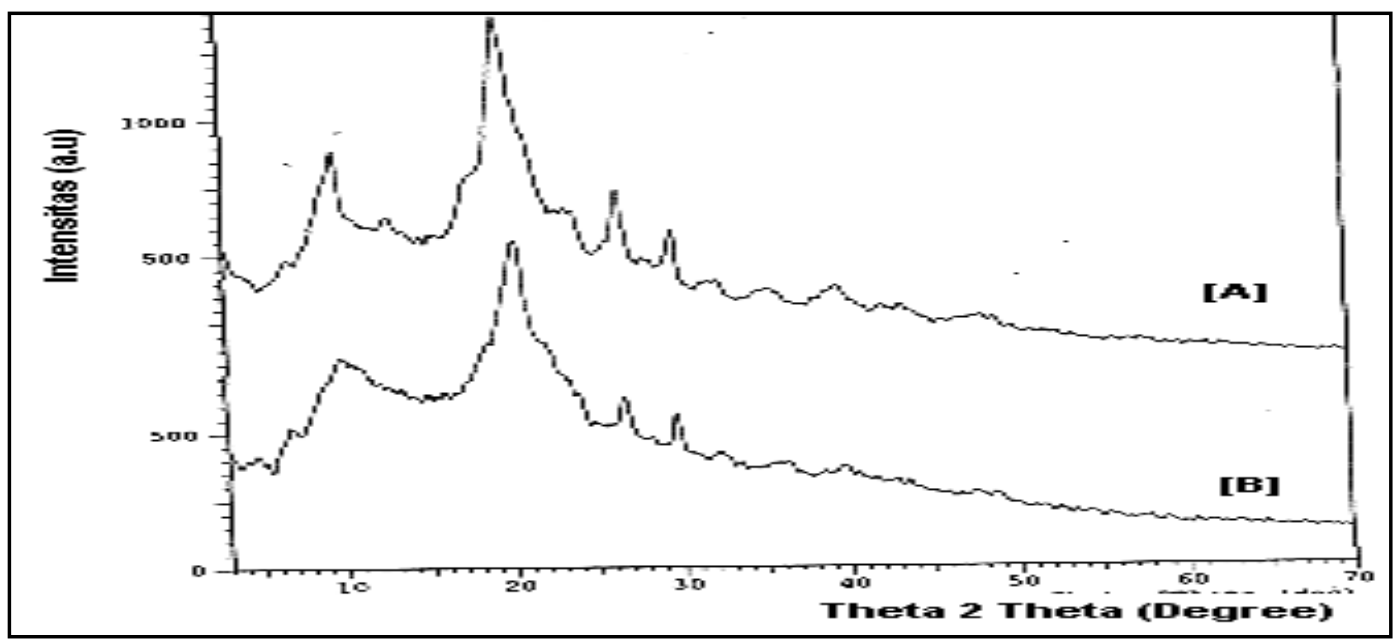

Gambar 3. Difraktogram (A). Kitin dan (B). Kitosan 
Difraktogram kitosan juga memperlihatkan puncak-puncak di sekitar $2 \theta=10^{\circ}$ dan $20^{\circ}$ yang merupakan puncakpuncak karakteristik kitosan (Cervera et al., 2004., Modrzejewska et al., 2006). Kitosan dengan puncak difraksi pada $2 \theta$ $=10^{\circ}$ dan $20^{\circ}$ menurut Ogawa dan Yui (1993) berbentuk terhidrat dan bersifat semikristalin. Pada difraktogram kitosan, puncak di $\theta=10^{\circ}$ dan $20^{\circ}$ lebih lebar dibandingkan pada kitin menunjukkan bahwa kitosan lebih amorf atau kurang bersifat kristalin dibandingkan dengan kitin. Hal ini menunjukkan telah terjadinya proses deasetilasi.

\section{Sintesis Membran Kitosan}

Membran kitosan merupakan senyawa derivat kitosan yang disintesis dari kitosan yang diperoleh dari hasil preparasi serbuk cangkang kepiting. Membran adalah suatu lapisan yang memisahkan dua fase dimana pemisahannya dapat diatur dan hanya dapat dilewati oleh ion-ion tertentu. Komponen aktif membran adalah suatu senyawa bermuatan atau netral yang mampu membentuk senyawa kompleks dengan ion-ion secara reversibel dan membawanya melalui membran organik (Meriatna, 2008). Membran kitosan disintesis dengan melarutkan kitosan dalam asam asetat dan selanjutnya ditambahkan agen ikat silang (croslink agent) yaitu glutaraldehid.

Kitosan mempunyai sifat yang sukar larut dalam air, basa kuat, dan asam sulfat, tetapi sedikit larut dalam asam klorida, asam nitrat, dan asam fosfat. Kelarutannya tinggi dalam asam organik lemah atau pelarut organik lain dengan tingkat keasaman di bawah 6,5 (Mekawati et al., 2000). Dalam proses pelarutan kitosan tidak sepenuhnya larut sempurna maka dari itu dilakukan pengadukan dengan magnetik stirer hingga kitosan dapat larut sempuran. Larutan kitosan yang dihasilkan berwarna kecoklatan. Kemudian larutan kitosan dikeringkan hingga terbentuk membran dengan menggunakan petridis. Dibutuhkan waktu kurang lebih dua hari untuk mengeringkan membran pada suhu $25^{\circ} \mathrm{C}$.

Setelah terbentuk membran kitosan, selanjutnya membran kitosan dicelupkan dalam $\mathrm{NaOH} 1 \%$, dalam hal ini $\mathrm{NaOH}$ berfungsi sebagai koagulan. Setelah itu diambil dan dicuci dengan aquades sampai $\mathrm{pH}$ netral. Tahap berikutnya direndam dalam gluteraldehid $0,4 \%$ yang berfungsi sebagai agen pengikat silang, agen pengikat silang atau crosslink agent berfungsi untuk menstabilkan membran kitosan karena membran kitosan resisten terhadap asam sehingga untuk menstabilkan membran kitosan pada kondisi asam maka reaksi ikat silang digunakan, selain itu tanpa reaksi ikat silang membran kitosan akan cepat rusak. Reaksi ikat silang glutaraldehid dengan kitosan terjadi melalui reaksi basa Schiff, dimana gugus aldehid glutaraldehid dengan gugus amina kitosan membentuk gugus imina (Roberts, 1992; Rorrer et al., 1993; Guibal et al. 1998), sebagaimana pada Gambar 4.

\section{Karakterisasi Membran Kitosan}

a. Penampilan fisik membran kitosan

Membran kitosan yang dibuat dengan menggunakan glutaraldehida sebagai agen cross-linkernya, hasilnya ditampilkan pada Gambar 5.

Berdasarkan gambar penampilan fisik membran kitosan di atas, maka dapat disimpulkan bahwa membran kitosan telah terbentuk. Membran kitosan yang dihasilkan berwarna agak kecoklatan dan berupa lembaran tipis. Membran kitosan yang dihasilkan mempunyai tekstur permukaan yang homogen dan halus. Pada permukaan membran kitosan tidak ada noda-noda partikel yang tidak larut. Hal ini menunjukkan bahwa semua partikel kitosan larut dan membentuk membran. 


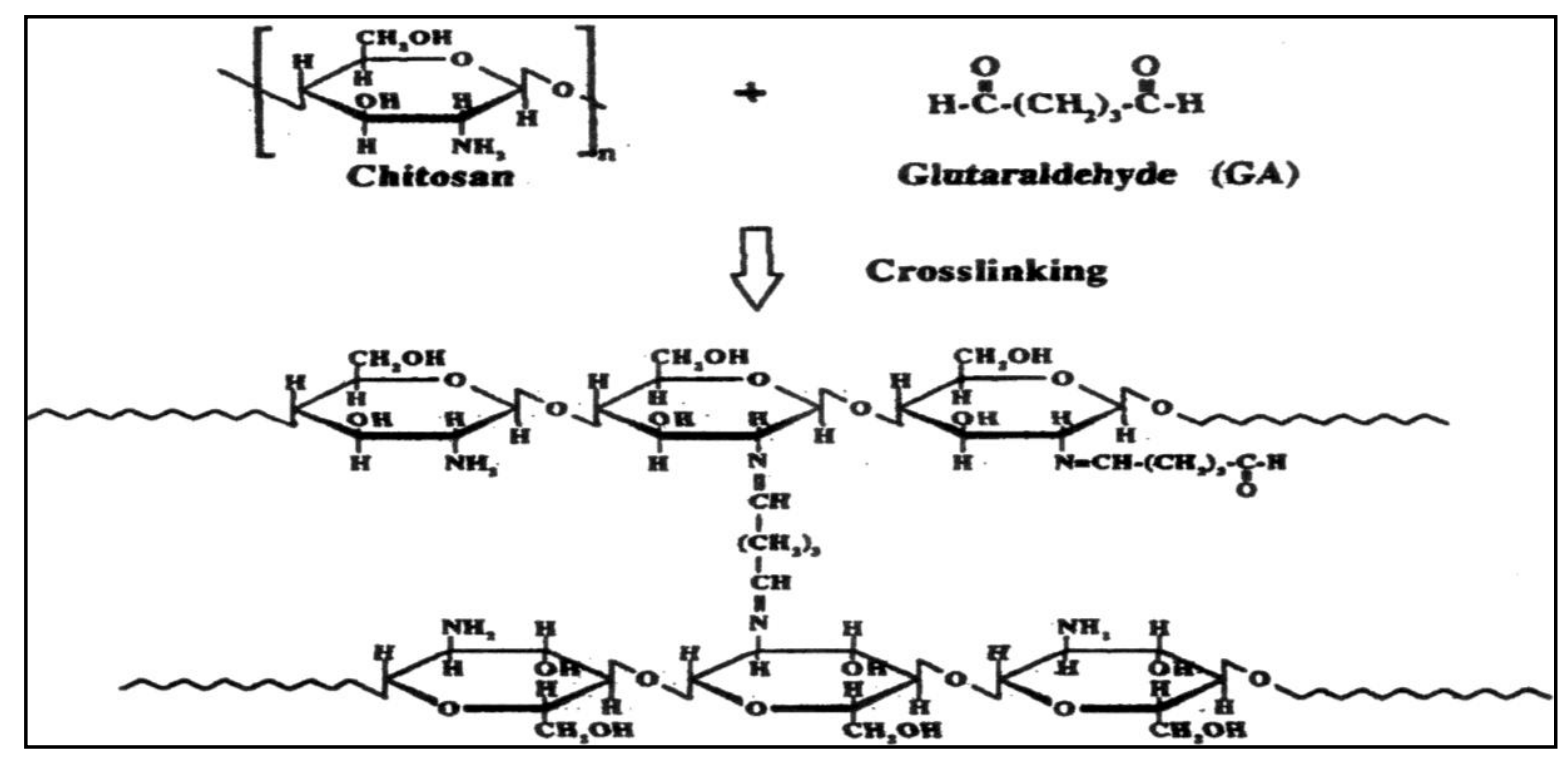

Gambar 4. Reaksi ikat silang antara kitosan dengan glutaraldehid.
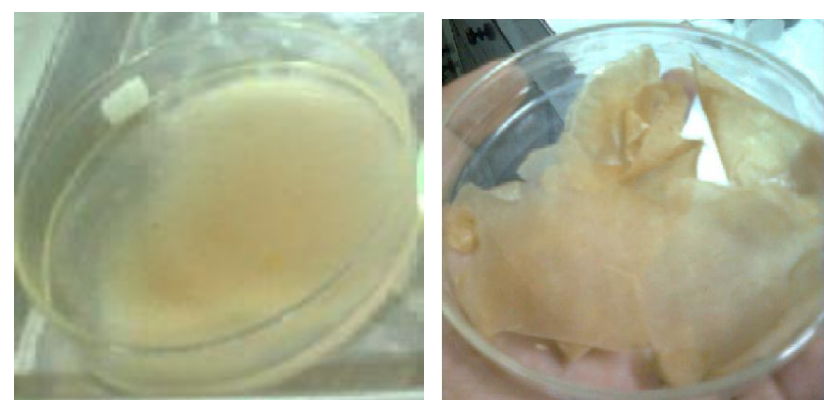

Gambar 5. (A). Membran kitosan setelah pengeringan, (B). Membran kitosan setelah pencucian dengan akuades

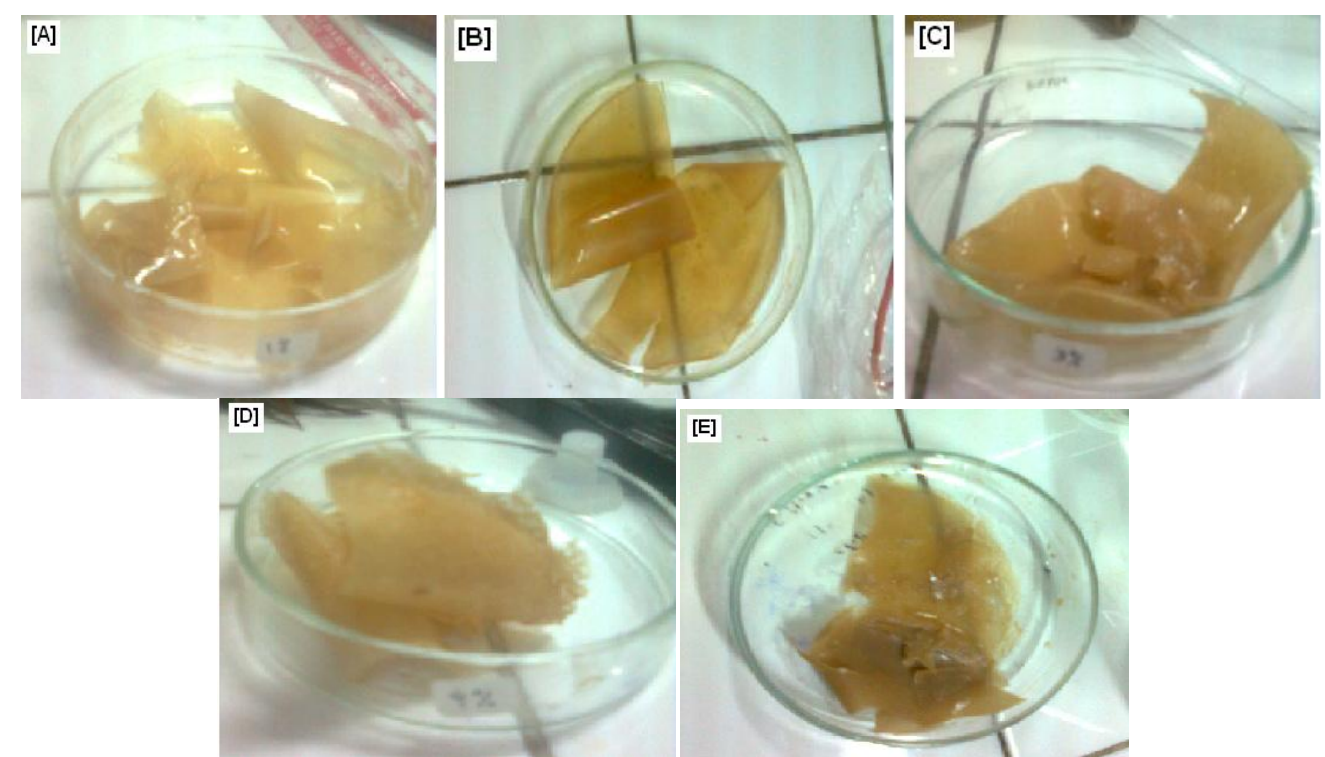

Gambar 6. (A). Membran kitosan 1\%, (B). Membran kitosan 2\%, (C). Membran kitosan 3\%, (D). Membran kitosan 4\%, dan (E). Membran kitosan 5\%. 


\section{b. Pengaruh konsentrasi kitosan terhadap kualitas membran kitosan}

Berdasarkan penampilan fisik membran kitosan dengan variasi konsentrasi pada Gambar 6, terlihat bahwa semakin tinggi konsentrasi kitosan yang digunakan untuk membuat membran, maka membran yang dihasilkan akan menunjukkan warna yang pekat dan kurang transparan. Hal ini kemungkinan disebabkan oleh semakin banyaknya partikel kitosan yang larut dan membentuk membran.

\section{c. Analisis gugus fungsi}

Berdasarkan analisis spektra IR membrane kitosan berbagai konsentrasi diketahui (Gambar 5) adanya puncak serapan di bilangan gelombang 1658,78 cm-1 yang menunjukkan serapan stretching $\mathrm{C}=\mathrm{O}$ pada spektra IR membran kitosan lebih nyata dibandingkan serbuk kitosan. Hal ini kemungkinan disebabkan adanya tambahan gugus aldehida dari glutaraldehida.

Secara umum spektra IR serbuk kitosan dan membran kitosan tidak ada perbedaan. Hal ini menunjukkan bahwa struktur kimia kitosan dalam bentuk membran tidak berubah.

\section{d. Kristalinitas}

Hasil difraktogram XRD membrane kitosan dengan berbagai konsentrasi dapat dilihat pada Gambar 8 . Berdasarkan difraktogram XRD membrane kitosan tampak bahwa pada membrane kitosan konsentrasi $1 \%$ sampai $4 \%$ puncak-puncak karakteristik kitosan yang menunjukkan tingkat kristalinitasnya akibat adanya ikatan hydrogen antaramolekul dan intramolekul semakin menghilang. Hal ini menunjukkan bahwa kitosan dalam bentuk membrane telah telah mengalami perubahan dalam keteraturan ikatan antar rantai polimernya. Ikatan hydrogen antar dan dalam rantai polimer kitosan kemungkinan telah terkalahkan oleh terjadinya ikatan baru yaitu ikatan antara rantai polimer kitosan dengan glurataldehida.

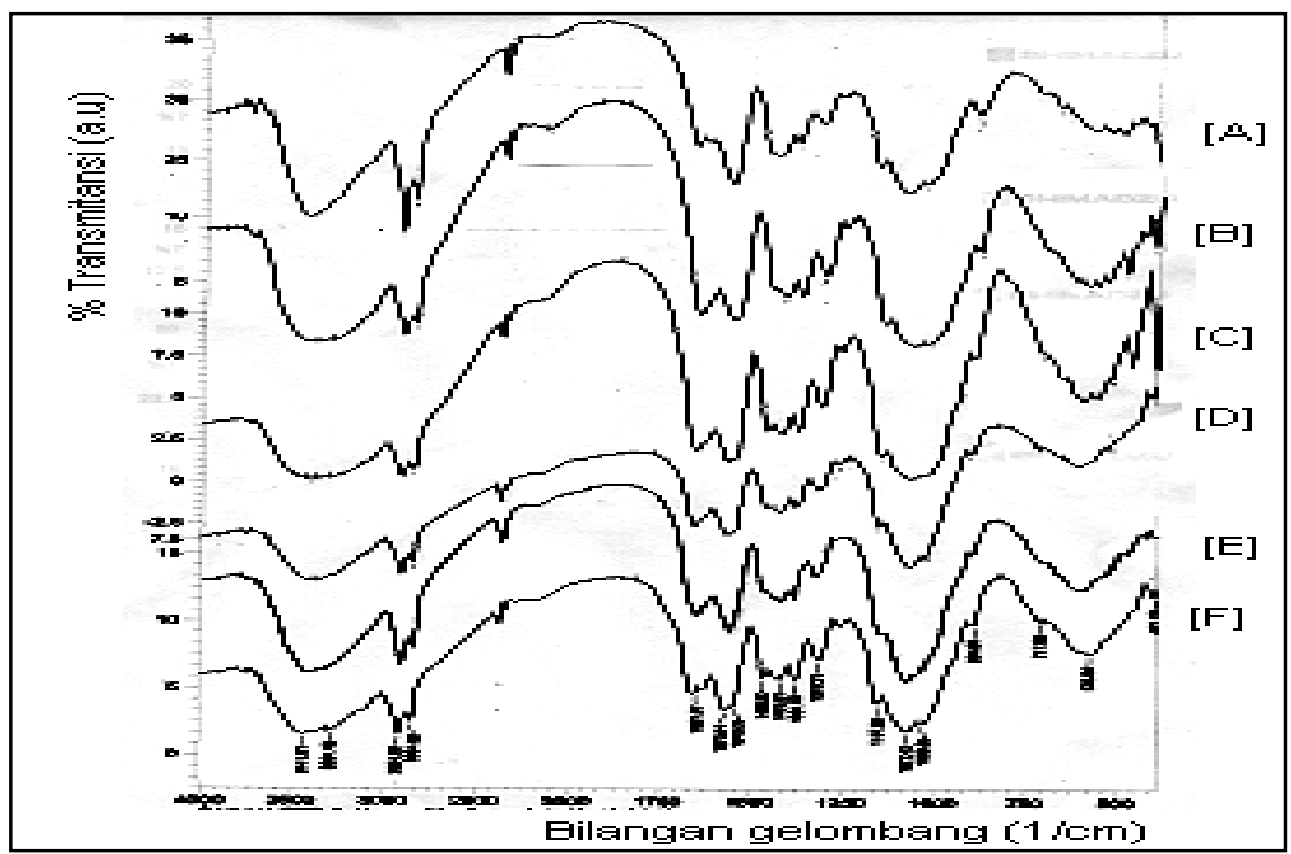

Gambar 7. Spektra IR (a). Kitosan, (b). Membran kitosan 1\%, (c). Membran kitosan 2\%, (d). Membran kitossan 3\%, (e). Membran kitosan 4\%, dan (f). Membran kitosan $5 \%$. 


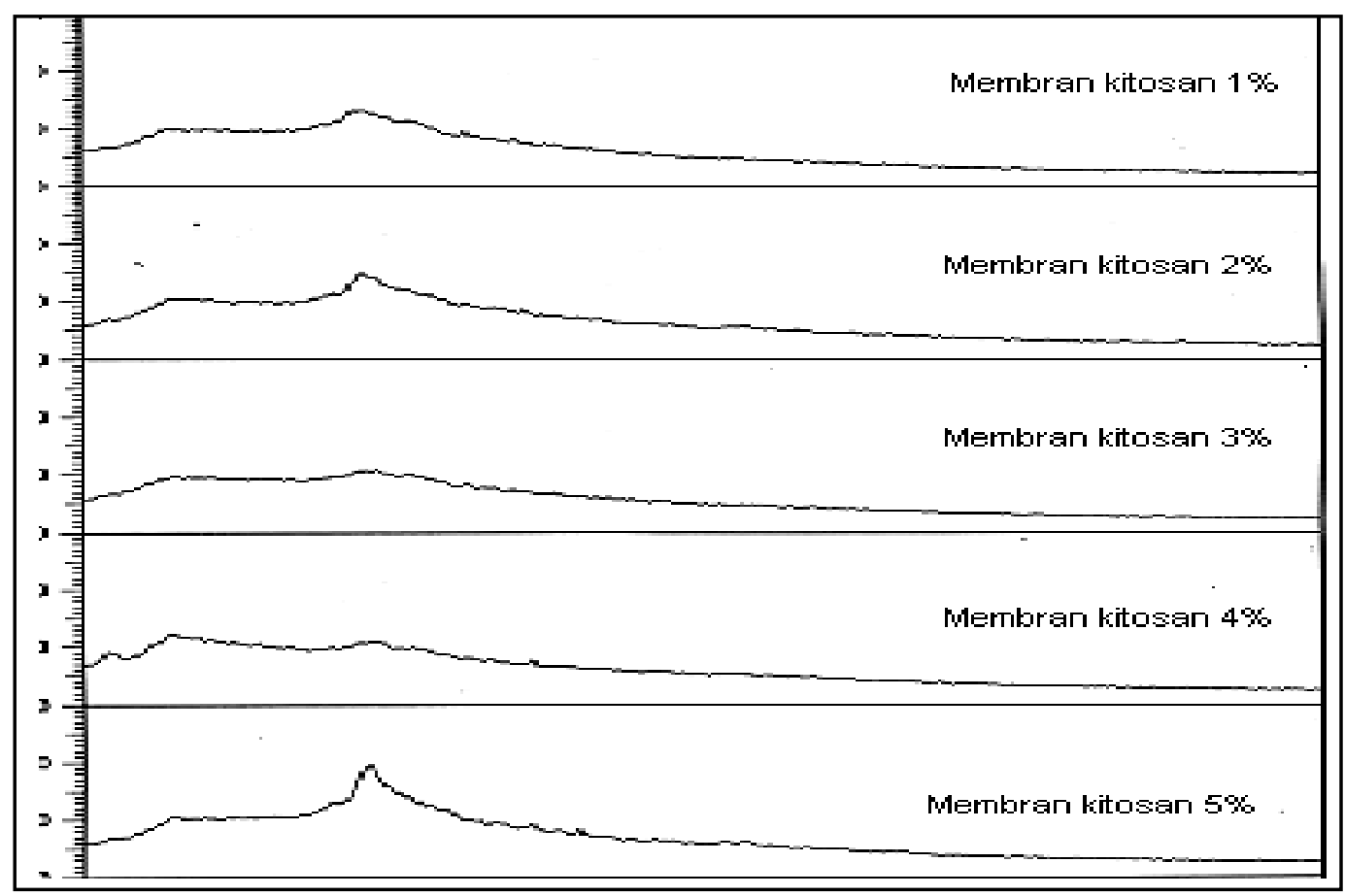

Gambar 8. Difraktogram XRD membran kitosan

Pada membran kitosan konsentrasi $5 \%$, puncak di $2 \theta=20^{\circ}$ muncul kembali. Hal ini kemungkinan disebabkan terlalu banyaknya kitosan yang dibuat membrane dan tidak semua serbuk kitosan larut. Perkiraan ini didasarkan atas fakta bahwa membrane kitosan 5\% mempunyai warna paling pekat. Serbuk kitosan yang tidak larut inilah yang diduga terdeteksi oleh XRD dengan kemunculan puncak di $2 \theta=20^{\circ}$.

\section{KESIMPULAN}

Hasil penelitian menyimpulkan bahwa:

1. Kitosan dapat dipreparasi dari limbah cangkang kepiting melalui proses deproteinasi, demineralisasi, dan deasetilasi.,

2. Membran kitosan dapat disintesis dari serbuk kitosan dengan menggunakan agen crosslinking glurataldehida.,

3. Semakin tinggi konsentrasi kitosan yang digunakan untuk membuat membran, maka membran yang dihasilkan akan menunjukkan warna yang pekat dan kurang transparan,

4. Struktur kimia kitosan dalam bentuk membran kitosan tidak mengalami perubahan tetapi kristalinitasnya berubah.

\section{UCAPAN TERIMA KASIH}

Tim Peneliti mengucapkan terima kasih kepada Ketua LPPM Universitas Sebelas Maret atas bantuan biaya penelitian sesuai Surat Perjanjian Pelaksanaan Penelitian Nomor: 448/H27.11/PL/2010.

\section{DAFTAR PUSTAKA}

Baxter, S., Zivanovic, S. and Weiss, J., 2005, Molecular Weight and Degree of Acetylation of HighIntensity Ultrasonicated Chitosan, Food Hydrocolloids, Vol.19, 821-830.

Cervera, M. F., Heinamaki, J., Rasanen, M., Maunu, S. L., Karjalainen, 
M., Acosta, O. M. N., Colarte, A. I. and Yliruusi, J., 2004, Solidstate Characterisation of Chitosans Derived from Lobster Chitin, Carbohydr.Polym, Vol.58, 401-408.

Dewi, Ariyanti Suhita \& Fawzya, Yusro Nuri, 2006, Studi Pendahuluan: Penggunaan Berulang Larutan Natrium Hidroksida dalam Pembuatan Kitosan, Prosiding Seminar Naional Himpunan Kimia Indonesia 2006, Departemen FMIPA Institut Pertanian Bogor. Balai Besar Riset Pengolahan Produk dan Bioteknologi Kelautan dan Perikanan, 154-161

Dyahningtyas, T.E., 1999, Penghilangan Kadmium (Cd) dengan Menggunakan Chitosan, Prosiding Seminar Nasional Kimia $V$, Laboratorium Kimia Anorganik FMIPA UGM Yogyakarta, tanggal 8-9 Maret 1999.

Franco, L. O., Maia, R.C., Porto, A.L.F., Messias, A.S., Fukushima, K. and Campos-Takaki, G.M., 2004, Heavy Metal Biosorption by Chitin and Chitosan Isolated from Cunninghamella elegans (IFM 46109), Braz.J.Microbiol., Vol.35, No.3.

Guzel, F. and Uzun, I., 2000, Adsorption of Some Heavy Metal Ion from Aqueous Solution by Activated Carbon and Comparison of Percent Adsorption Result of Activated Carbon with Those of Some Other Adsorbent, Turk. J. Chem., Vol.24, 291-297.

Karthikeyan, G., Anbalagan, K. and Andal, N.M., 2004, Adsorption Dynamic and Equilibrium Studies of $\mathrm{Zn}$ (II) onto Chitosan,
J. Chem. Sci., Vol.116, No.02, 119-127.

Meriatna, 2008, Penggunaan Membran Kitosan untuk Menurunkan Kadar Logam Krom (Cr) dan Nikel (Ni) dalam Limbah Cair Industri Pelapisan Logam, Tesis, Program Studi Teknik Kimia, Sekolah Pascasarjana Universitas Sumatra Utara.

Mekawati, Fachriyah E, dan Sumardjo, D, 2000, Aplikasi Kitosan Hasil tranformasi Kitin Limbah Udang (Penaeus merguiensis) untuk Adsorpsi Ion Logam Timbal, Jurnal Sains and Matematika, Vol. 8, No.2, 51-54.

Panggabean, A.S., 2001, Pembuatan dan Karakterisasi Membran Elektroda Selektif Ion $\mathrm{Cd}^{2+}-$ Kitosan sebagai Sensor Kimia, Tesis, Program Studi Kimia, Program Pascasarjana Universitas Sumatra Utara.

Rege, P. R. and Block, L. H., 1999, Chitosan Processing : Influence of Process Parameters during Acidic and Alkaline Hydrolysis and Effect of the Processing Sequence on the Resultant Chitosan's Properties, Carbohydr.Res., Vol.321, 235245.

Saputro, Agung Nugroho Catur, 2009, Pengaruh Metode Preparasi Kitosan terhadap Sifat Kitosan dan Aplikasinya sebagai Agen Antibakteri pada Kain Katun, Tesis, Program Pascasarjana Ilmu Kimia, Jurusan Kimia FMIPA UGM, Yogyakarta

Saputro, Agung Nugroho Catur., Kartini, I. dan Sutarno, 2009, Pengaruh Metode Preparasi Kitosan terhadap Sifat Karakteristik Kitosan, Makalah Seminar Nasional Kimia dan Pendidikan 
Kimia di Prodi Kimia PMIPA FKIP UNS.

Suhendrayatna, 2001, Bioremoval Logam Berat Dengan Menggunakan Microorganisme: Suatu Kajian Kepustakaan, Seminar on-Air Bioteknologi untuk Indonesia Abad 21, Sinergy Forum - PPI Tokyo Institute of Technology, tanggal 1-14 Februari 2001.

Yanming, D., Congyi, X., Jianwei, W., Mian, W., Yusong, W. and Yonghong, R., 2001, Determination of Degree of Substitution for N-Acylated Chitosan using IR Spectra, Sci.China, Ser.B, Vol.44, No.2, 216-224. 